\title{
Prognostic factors following enucleation of 111 uveal melanomas
}

\author{
Kate Coleman, Jan P A Baak, Paul Van Diest, Joan Mullaney, Michael Farrell, Maurice Fenton
} Department of Pathology
and the Research Foundation, The Royal Victoria Eye and Ear Hospital, Adelaide Road, Dublin 2, Ireland $\mathrm{K}$ Coleman J Mullaney

M Farrell

M Fenton

Department of Pathology, The Free University Hospital, Amsterdam, The Netherlands J P A Baak P Van Diest

Correspondence to: Ms Kate Coleman, The Research Foundation, The Royal Victoria Eye and Ear Hospital, Adelaide Road Dublin 2, Ireland.

Accepted for publication 13 July 1993

Figure 1 Survival curve showing death from metastases following enucleation for uveal melanoma $(p<0 \cdot 0001)$

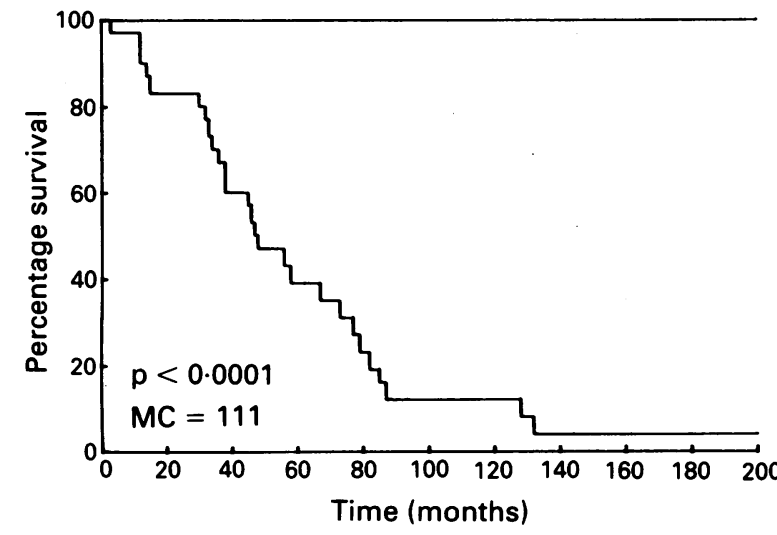
No metastases

At risk

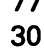

Abstract

Follow up information was retrieved on 111 patients who underwent enucleation for uveal melanoma between 1964 and 1987, allowing a minimum postoperative period of 5 years. Univariate survival analysis was carried out using Kaplan-Meier curves and the differences between the curves were analysed with the Mantel-Cox test. Multivariate analysis used the Cox proportional hazards model. Univariate analysis isolated each of the following as significant prognosticators: largest tumour diameter (LTD) $(\mathbf{p}<0.002)$, presence of epithelioid cells $(\mathbf{p}<0.03)$, and glaucoma $(p<0.001)$. A combination of cell type, glaucoma, and LTD $(p<0.0001)$ had strong and independent prognostic significance in multivariate analysis. The results of this series are compared with previous studies and the value of cell type information and new quantitative parameters is discussed.

(Br F Ophthalmol 1993; 77: 688-692)

The clinical course of patients with uveal melanoma is capricious. These tumours typically comprise cell types of differing degrees of malignancy and doubling times. Although most postoperative metastases present within the first 5 years of enucleation, some have become manifest up to 36 years later. ${ }^{1}$ It is unclear whether a patient benefits more if the eye is enucleated or is treated by observation alone, eye wall resection, or irradiation. It has been hypothesised that intervention procedures may accelerate the rate of development of metastases. ${ }^{234}$

Survival statistics in patients with uveal

Metastases

$30 \quad 18$

40
6
22

3
1 no metastases 1 metastases melanomas are available from countries including Northern Ireland, ${ }^{5}$ Finland, ${ }^{6}$ Denmark, ${ }^{78}$ England ${ }^{910}$ and several different study groups in North America. ${ }^{311} 121314$ The Collaborative Ocular Melanoma Study (COMS) is a set of multicentre prospective clinical trials established in North America and Canada in 1986, and is the first reported prospective study which has been designed to evaluate interventions used to treat patients with choroidal melanomas. The minimal follow up time is 10 years. ${ }^{15}$ However, because of the slow growth rate of some melanomas, it is expected that more than 30 years will elapse before all useful information is harnessed. Until then, survival analysis on as many different populations as possible may aid therapeutic decisions. With this in mind, we set out to evaluate survival following enucleation in 111 patients with uveal melanoma, and to compare our findings with published results.

\section{Materials and methods}

A total of 373 uveal melanomas were diagnosed in the National Ophthalmic Pathology Laboratory of The Royal Victoria Eye and Ear Hospital, Dublin, from January 1964 to July 1987. Enucleation was performed in each instance. Follow up information was collected by sending questionnaires to all referring ophthalmologists for the following information: survival, or date and cause of death; evidence of local spread; evidence of metastases; evidence of another neoplasm; and name of local physician. Questionnaires were also forwarded to the patient's physician where necessary and other doctors involved in the patient's care were contacted by telephone. It was decided that direct contact with relatives was not warranted for the purpose of this study. Full clinical information became available in 111 patients. The maximum follow up time was 24 years, the median was 11.5 years, and the minimum, 5 years. Distribution of age and sex was similar to the original group of 373 .

Pathology details were obtained from the original pathology reports. The site of the tumour was described as either anterior or posterior to the equator, equatorial, or involving the ciliary body. The largest tumour dimension (LTD) was recorded, but in some cases only qualitative data were available - for example, 'tumour fills globe', and in such cases the largest dimension from either preoperative clinical estimation or glass slide measurements was used. Ophthalmologically and pathologically assessed 
Table 1 Summary of statistics on 111 uveal melanomas

\begin{tabular}{|c|c|c|c|c|c|}
\hline Variable & $n$ & $\begin{array}{l}\text { Metastases } \\
n(\%)\end{array}$ & $\begin{array}{l}\text { Alive } \\
n(\%)\end{array}$ & p Value & $\begin{array}{l}\text { Mantel- } \\
\text { Cox }\end{array}$ \\
\hline \multicolumn{6}{|l|}{ Sex } \\
\hline $\begin{array}{l}\text { Male } \\
\text { Female }\end{array}$ & $\begin{array}{l}53 \\
58\end{array}$ & $\begin{array}{l}15(28) \\
18(29)\end{array}$ & $\begin{array}{l}38(72) \\
40(71)\end{array}$ & 0.69 & $0 \cdot 2$ \\
\hline \multicolumn{6}{|l|}{ Age (years) } \\
\hline $\begin{array}{l}<60 \\
\geqslant 60\end{array}$ & $\begin{array}{l}60 \\
51\end{array}$ & $\begin{array}{l}17(28) \\
16(31)\end{array}$ & $\begin{array}{l}47(72) \\
35(69)\end{array}$ & $0 \cdot 16$ & $2 \cdot 0$ \\
\hline \multicolumn{6}{|l|}{ Age (years) } \\
\hline $\begin{array}{l}<40 \\
40-60 \\
>60\end{array}$ & $\begin{array}{l}13 \\
47 \\
51\end{array}$ & $\begin{array}{l}2(15) \\
15(32) \\
16(31)\end{array}$ & $\begin{array}{l}11(85) \\
32(68) \\
35(69)\end{array}$ & $0 \cdot 27$ & $2 \cdot 6$ \\
\hline \multicolumn{6}{|l|}{ Metastases } \\
\hline Orbit & 2 & $1(50)$ & $1(50)$ & $<0.0001$ & $209 \cdot 7$ \\
\hline Lung & 2 & $2(100)$ & & & \\
\hline Liver & 24 & $24(100)$ & & & \\
\hline Other & 4 & $4(100)$ & & & \\
\hline None & 79 & & $77(100)$ & & \\
\hline \multicolumn{6}{|l|}{ Metastases } \\
\hline $\begin{array}{l}\text { Yes } \\
\text { No }\end{array}$ & $\begin{array}{l}32 \\
79\end{array}$ & $32(100)$ & $\begin{array}{l}0 \\
77(100)\end{array}$ & $<0.0001$ & $113 \cdot 0$ \\
\hline \multicolumn{6}{|l|}{ Other metastases } \\
\hline $\begin{array}{l}\text { Yes } \\
\text { No }\end{array}$ & $\begin{array}{l}11 \\
91\end{array}$ & $\begin{array}{l}11(100) \\
16(17)\end{array}$ & $\begin{array}{l}0 \\
75(83)\end{array}$ & $<0.0001$ & $54 \cdot 7$ \\
\hline Unknown & $\begin{array}{l}71 \\
9\end{array}$ & $\begin{array}{r}10(11) \\
6(77)\end{array}$ & $3(33)$ & & \\
\hline \multicolumn{6}{|l|}{ LTD } \\
\hline $\begin{array}{l}<10 \mathrm{~mm} \\
10-15 \mathrm{~mm}\end{array}$ & $\begin{array}{l}42 \\
57\end{array}$ & $\begin{array}{r}8(19) \\
17(30)\end{array}$ & $\begin{array}{l}36(81) \\
40(70)\end{array}$ & 0.002 & $12 \cdot 8$ \\
\hline$>15 \mathrm{~mm}$ & 12 & $8(77)$ & $\begin{array}{c}40(10) \\
4(33)\end{array}$ & & \\
\hline \multicolumn{6}{|l|}{ LTD } \\
\hline $\begin{array}{l}<10 \mathrm{~mm} \\
\geqslant 10 \mathrm{~mm}\end{array}$ & $\begin{array}{l}42 \\
69\end{array}$ & $\begin{array}{r}8(19) \\
25(36)\end{array}$ & $\begin{array}{l}36(81) \\
44(64)\end{array}$ & 0.03 & $4 \cdot 7$ \\
\hline \multicolumn{6}{|l|}{ Glaucoma } \\
\hline Yes & 36 & $19(53)$ & $17(47)$ & 0.001 & $10 \cdot 5$ \\
\hline $\begin{array}{l}\text { No } \\
\text { Detachment. }\end{array}$ & 75 & $14(19)$ & $61(81)$ & & \\
\hline \multicolumn{6}{|l|}{ Detachment. } \\
\hline No & 17 & $2(92)$ & $15(88)$ & $0 \cdot 11$ & $2 \cdot 6$ \\
\hline \multicolumn{6}{|l|}{ Cell type } \\
\hline Pure spindle & 53 & $13(25)$ & $40(75)$ & 0.03 & $4 \cdot 5$ \\
\hline $\begin{array}{l}\text { Part epith } \\
\text { Cell type. }\end{array}$ & 55 & $20(36)$ & $35(64)$ & & \\
\hline \multicolumn{6}{|l|}{ Cell type. } \\
\hline Spindle B & 33 & $8(24)$ & $\begin{array}{r}5(83) \\
25(76)\end{array}$ & 0.04 & $11 \cdot 4$ \\
\hline Spindle A/B & 14 & $4(29)$ & $10(71)$ & & \\
\hline Spl/Epith & 32 & $10(31)$ & $22(69)$ & & \\
\hline Epith/Spl & 23 & $10(43)$ & $13(57)$ & & \\
\hline Necrotic & 3 & 0 & $3(100)$ & & \\
\hline \multicolumn{6}{|l|}{ Pigment } \\
\hline None/low & 21 & $4(19)$ & $17(81)$ & $0 \cdot 73$ & 0.63 \\
\hline Medium & 71 & $24(34)$ & $47(66)$ & & \\
\hline $\begin{array}{c}\text { High } \\
\text { Paition }\end{array}$ & 19 & $5(26)$ & $14(74)$ & & \\
\hline \multicolumn{6}{|l|}{ Position } \\
\hline Posterior & 84 & $21(25)$ & $63(75)$ & $0 \cdot 2$ & 1.6 \\
\hline Other & 27 & $12(44)$ & $15(56)$ & & \\
\hline Position & & & & & \\
\hline Iris & 3 & $1(33)$ & $2(67)$ & 0.58 & $2 \cdot 9$ \\
\hline Ciliary body & 12 & $5(42)$ & $7(58)$ & & \\
\hline Posterior & 84 & $21(25)$ & $63(75)$ & & \\
\hline Anterior & 7 & $3(43)$ & $4(57)$ & & \\
\hline Equator & 5 & $3(60)$ & $2(40)$ & & \\
\hline Spread & & & & & \\
\hline Yes & 47 & $20(43)$ & $27(57)$ & 0.08 & $3 \cdot 1$ \\
\hline No & 64 & $13(20)$ & $51(80)$ & & \\
\hline Spread & & & & & \\
\hline $\begin{array}{l}\text { Optic nerve/extrascleral } \\
\text { Other }\end{array}$ & $\begin{array}{l}17 \\
94\end{array}$ & $\begin{array}{r}7(41) \\
26(28)\end{array}$ & $10(59)$ & $0 \cdot 27$ & $1 \cdot 2$ \\
\hline Spread & & & & & \\
\hline Optic nerve & 9 & $4(44)$ & $5(56)$ & $0 \cdot 36$ & $3 \cdot 2$ \\
\hline Sclera & 30 & $13(43)$ & $17(57)$ & & \\
\hline Extrasceral & 8 & $3(37)$ & $5(63)$ & & \\
\hline None & 64 & $13(20)$ & $51(80)$ & & \\
\hline Eye & & & & & \\
\hline Right & 57 & $20(35)$ & $37(65)$ & $0 \cdot 74$ & $0 \cdot 11$ \\
\hline $\begin{array}{l}\text { Left } \\
\text { Vascularity }\end{array}$ & 54 & $13(24)$ & $41(76)$ & & \\
\hline Normal & 98 & $28(28)$ & $70(72)$ & 0.5 & 0.43 \\
\hline Increased & 13 & $5(38)$ & $8(62)$ & & \\
\hline
\end{tabular}

LTD= largest tumour dimension. same pathologist (JM). The Callender classification has since been updated ${ }^{18}$ but still fails to distinguish between the different types of spindle cell or mixed cell tumours. In this study, the pathology reports were reviewed and the Callender classification modified as follows: spindle A, spindle B, spindle A and B mixed, predominantly spindle with a few epithelioid cells, and predominantly epithelioid, with or without the presence of a few spindle cells. Pigmentation was described as mild (including the amelanotic group), moderate, or heavy.

\section{Data analysis}

For survival analysis, patients dying without clinically evident metastases were censored at that date and corrected (tumour related) survival time was used as the follow up parameter. Grouping was performed according to the different subgroups for each non-continuous variable. For the two continuous variables (age and LTD) in the single variate analysis, cut off points were chosen according to the literature. These were at $\mathbf{4 0}$ years and 60 years for age, and at 10 $\mathrm{mm}$ and $15 \mathrm{~mm}$ for LTD. Kaplan-Meier curves were plotted, and differences between the curves were analysed with the Mantel-Cox test. Multivariate survival analysis was also performed to evaluate additional prognostic value of the variables studies, using the enter and remove limit of 0.01 . The analysis was performed on all variables available at the time of surgery. All analyses were performed using the BMDP statistical package, with $p$ values below 0.05 being regarded as significant.

\section{Results}

Patient survival is shown in Figure 1. General statistics are summarised in Table 1 . There were 58 women $(52 \%)$ and 53 men (48\%). All patients were white. Age at enucleation ranged from 17 years to 91 years with a median age of 57.5 years. At the end of the study period, 45 (40.5\%) patients had died, $31(28 \%)$ with confirmed metastases as detected clinically before death. One patient was alive with orbital metastases. The possibility of metastases as a cause of death could not be ruled out in a further three patients and so, for statistical analysis, these were censored as being 'well'. Of the 32 patients with metastases, 24 had secondaries in the liver, two in the lung, two in the orbit, and one each with metastases of bone, colon, and brain. It was not possible to confirm the site of metastases in one patient. Ten of the patients with liver metastases were subsequently found to have metastases at other sites, including lung, bone, brain, pancreas, chest wall, colon, and skin.

Univariate survival analysis provided significant results for the following: LTD, with cut off points of $10 \mathrm{~mm}$ and $15 \mathrm{~mm}(\mathrm{p}<0.002)$ (see Fig $2)$ and glaucoma $(p<0 \cdot 001)$. When cell type was classified according to the presence or absence of epithelioid cells, significance was also reached $(p<0.03)$ (see Fig 3). The presence of retinal detachment was not significant, but there was a trend $(p<0 \cdot 11)$. As these features came out as signs in the single variate survival analysis, the $\chi^{2}$ recorded.

The tumours were originally classified according to the first Callender classification ${ }^{17}$ by the 


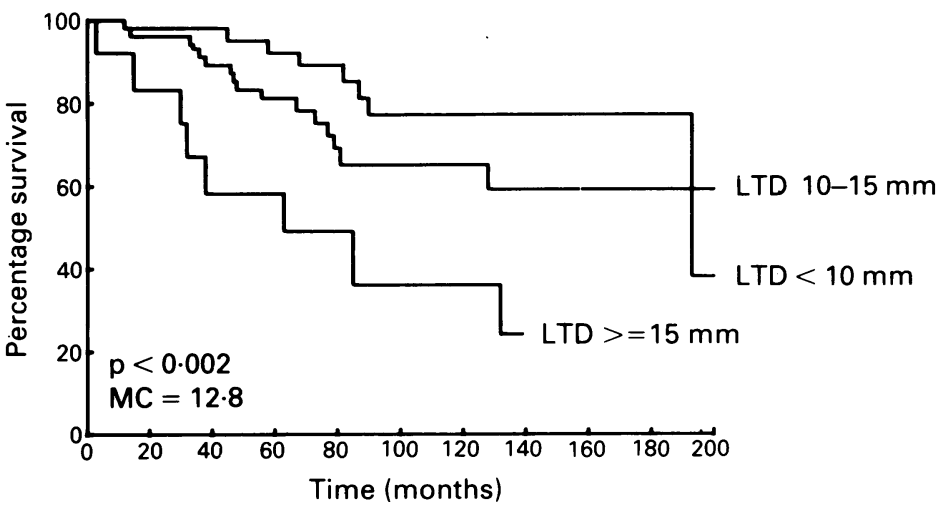

$\begin{array}{llllllll} & 42 & 40 & 23 & 12 & 7 & 0 & \text { LTD }<10 \\ \text { At risk } & 53 & 51 & 29 & 13 & 4 & 1 & \text { LTD } 10-15 \\ & 55 & 41 & 18 & 12 & 4 & 0 & \text { LTD }>-15\end{array}$

Figure 2 Survival curve for patients with largest tumour diameter (LTD) less than $10 \mathrm{~mm}$ between 10 and $15 \mathrm{~mm}$, and more than $15 \mathrm{~mm}(p<0.002)$.

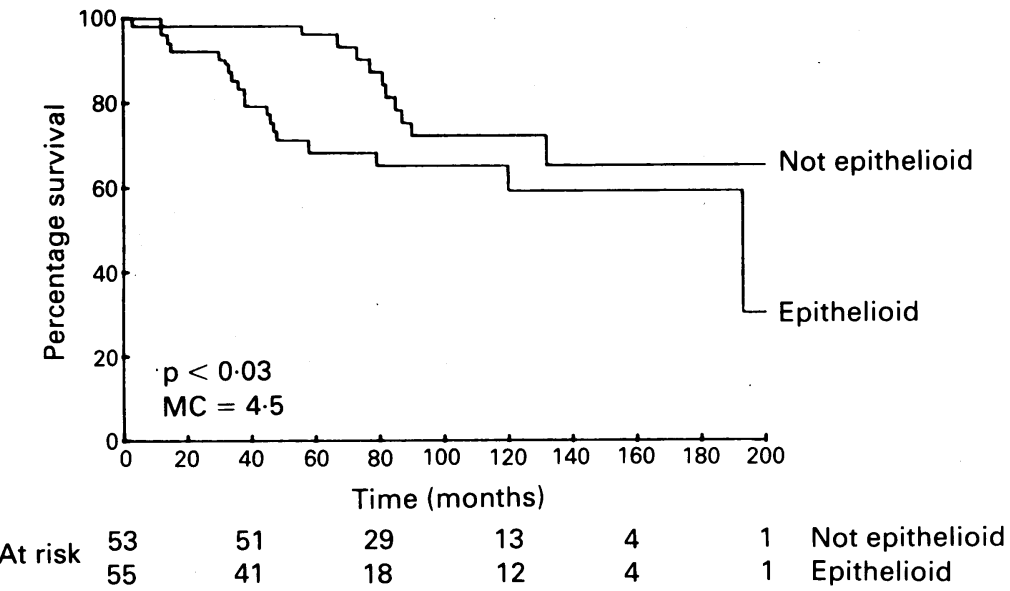

Figure 3 Survival curve for patients with uveal melanomas with and without epithelioid cells $(p<0.03)$.

Table 2 Correlation of LTD (largest tumour dimension) with cell type retinal detachment, and glaucoma ( $\chi^{2}$ test)

\begin{tabular}{|c|c|c|c|}
\hline$L T D$ & $<10 \mathrm{~mm}$ & $\geqslant 10 \mathrm{~mm}$ & p Value \\
\hline $\begin{array}{l}\text { Cell type }{ }^{\star} \text { : } \\
\text { Pure spindle } \\
\text { Part epithelioid }\end{array}$ & $\begin{array}{l}24 \\
17\end{array}$ & $\begin{array}{l}29 \\
38\end{array}$ & $<0 \cdot 12$ \\
\hline $\begin{array}{l}\text { Detachment } \\
\text { Yes } \\
\text { No }\end{array}$ & $\begin{array}{l}28 \\
14\end{array}$ & $\begin{array}{r}66 \\
3\end{array}$ & $<0.0001$ \\
\hline $\begin{array}{l}\text { Glaucoma: } \\
\text { Yes } \\
\text { No }\end{array}$ & $\begin{array}{l}11 \\
31\end{array}$ & $\begin{array}{l}25 \\
44\end{array}$ & $<0 \cdot 27$ \\
\hline
\end{tabular}

^Three cases were necrotic and so not evaluable.

Table 3 Multivariate analysis of uveal melanomas

\begin{tabular}{lllclll}
\hline Combination & & $n$ & $\begin{array}{c}\text { Metastases } \\
n(\%)\end{array}$ & $\begin{array}{l}\text { Alive } \\
n(\%)\end{array}$ & p Value & $\begin{array}{l}\text { Mantel- } \\
\text { Cox }\end{array}$ \\
\hline OC MEL-1 & $\leq 0.74$ & 54 & $8(15)$ & $46(85)$ & $<0.0005$ & 12.3 \\
OC MEL-2 & $>0.74$ & 57 & $24(42)$ & $28(58)$ & & \\
& $<0.3$ & 39 & $5(13)$ & $34(87)$ & $<0.0001$ & 17.6 \\
& $0 \cdot 3-1 \cdot 3$ & 38 & $9(24)$ & $29(76)$ & & \\
& $>1.3$ & 34 & $18(53)$ & $16(47)$ & &
\end{tabular}

Formula: $+0 \cdot 0897^{\star} \mathrm{LTD}$

$+0 \cdot 4449 \star$ cell type $(1=$ spindle $A, 2=$ spindle $\mathrm{B}, 3=$ spindle $\mathrm{A} / \mathrm{B}, 4=\mathrm{spl} /$ part epith,

$5=$ epith/part spl, $6=$ necrotic $)$
$-0.9977^{\star}$ glaucoma $(1=$ yes, $2=$ no

test was used to examine the correlation between LTD and cell type $(\mathrm{p}<0 \cdot 12)$, LTD and glaucoma $(p<0 \cdot 27)$, and LTD and retinal detachment $(p<0.0001)$ (see Table 2). The occurrence of metastases $(p<0.0001)$ and presence of more than one metastatic site $(p<0.0001)$ were, as expected, significantly correlated with shortened survival.

In multivariate survival analysis (see Table 3 ), a combination of LTD, cell type, and glaucoma emerged $(p<0.0001)$. Survival of patients according to this multivariate combination is shown in Figure 4. In order to allow a more accurate comparison of the significance of this combination with that of LTD, it was decided to attribute a similar number of cases to each group. A third set of cut off points was selected for LTD, dividing the patients into groups of 42,40 , and 29. This grouping also reached significance ( $\mathrm{p}<0.04$ and Mantel-Cox 6.3), but the MantelCox value and probability of the multivariate combination $(\mathrm{p}<0.0001$ and Mantel-Cox 17.6) are much better than that of any of the single variables.

\section{Discussion}

The purpose of this and other retrospective uveal melanoma survival studies has been to identify tumour characteristics that will help in deciding the most appropriate treatment and allow an accurate prognosis. This is the first survival analysis of uveal melanomas in the Republic of Ireland. Our 5-year survival rate of $72 \%$ is similar to that of the Northern Irish population (72\%), the London study group (78.1\%), ${ }^{9}$ and two American studies $\left(71 \%^{11}\right.$ and $\left.74 \%^{12}\right)$. Raivio reported a survival of $65 \%$ in Finland. ${ }^{6}$ His was an epidemiological study with $99 \%$ follow up, and thus may represent the most realistic melanoma survival rates. Although these figures are for patients who eventually underwent enucleation, this was not always the immediate form of treatment in every case. Packard, for example, included 22 cases where surgery followed growth of the tumour after a period of observation, and 72 cases which were managed conservatively. $\mathrm{He}$ also reported better survival figures in the non-surgical managed group. ${ }^{9} \mathrm{~A}$ recent meta-analysis of melanoma reports between 1966 and 1988 implies that the above figures may be optimistic, and that the combined weighted estimates of 5-year mortality rates following enucleation were $16 \%$ for small $(<10$ $\mathrm{mm})$ tumours, $32 \%$ for medium $(10-15 \mathrm{~mm})$ tumours, and $53 \%$ for large $(>15 \mathrm{~mm})$ tumours. ${ }^{13}$ This compares with the rates in the present study of $19 \%$ (small), $30 \%$ (medium), and $77 \%$ (large).

Of the four significant parameters in this series, information on only three - that is, LTD, glaucoma, and retinal detachment, was available before a decision to operate. We examined the usefulness of these signs as clinical guidelines (see Table 4). LTD has been the most important clinical characteristic to emerge from retrospective studies, ${ }^{13}$ but the cut off values, used by different investigators to predict optimal survival, vary. ${ }^{141920}$ Furthermore, there is wide interobserver variation of clinical estimation of LTD despite the assistance of ultrasonography. Although the sensitivity of LTD as a prognostic parameter is good at $76 \%$, the specificity of only $44 \%$ still allows for a $56 \%$ chance of a false positive prediction of outcome.

The presence of glaucoma as a preoperative predictor of metastasis may be more useful. Both 


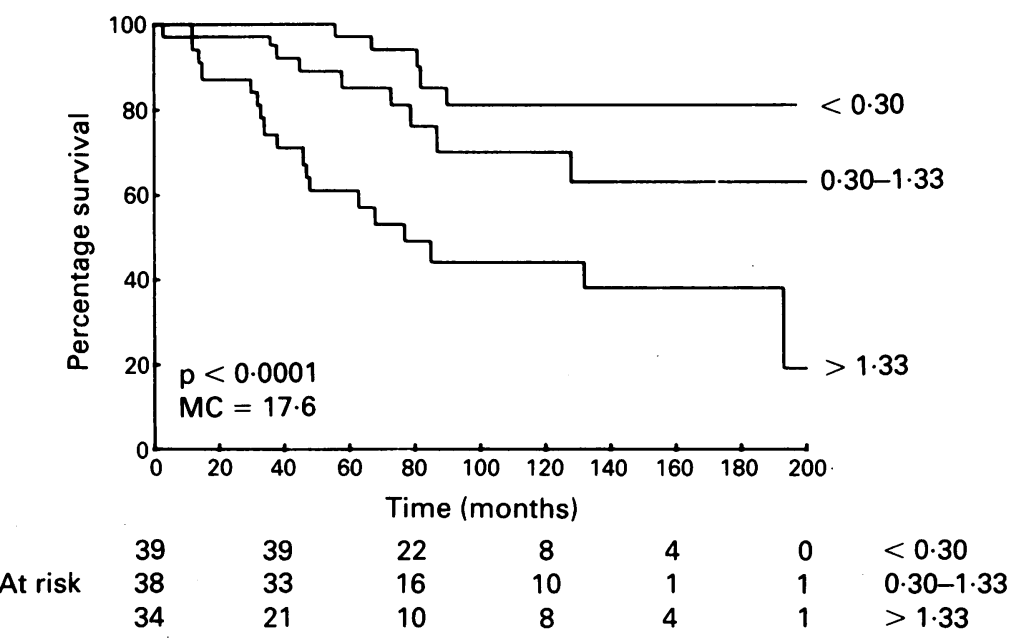

Figure 4 Survival curve for multivariate combination of largest tumour diameter (LTD), cell type, and glaucoma $(p<0.0001)$.

the sensitivity and specificity were reasonable, with a predictive positive value of $53 \%$. Although glaucoma is a frequent complication of uveal melanomas and is usually produced by large diffuse tumours, ${ }^{21}$ the correlation between LTD and glaucoma failed to reach significance $(p<0 \cdot 27)$. This points to mechanisms other than those occurring as a function of size. Microscopic tumour seeding of the trabecular meshwork will also raise intraocular pressure, and may be associated with concurrent haematogenous seeding and development of metastases.

Retinal detachment was a frequent finding, but was not a significant influence on survival.

Table 4 Predictive value of prognostic parameters for uveal melanomas

\begin{tabular}{llllll}
\hline & $\begin{array}{l}\text { LTD } \\
(\%)\end{array}$ & $\begin{array}{l}\text { Glaucoma } \\
(\%)\end{array}$ & $\begin{array}{l}\text { Cell type } \\
(\%)\end{array}$ & $\begin{array}{l}\text { RD } \\
(\%)\end{array}$ & $\begin{array}{l}\text { Multivariate } \\
(\%)\end{array}$ \\
\hline Sensitivity & 76 & 58 & 61 & 94 & 75 \\
Specificity & 44 & 78 & 53 & 19 & 58 \\
Predictive (positive) & 36 & 53 & 36 & 33 & 42 \\
Predictive (negative) & 81 & 81 & 76 & 88 & 85 \\
\hline
\end{tabular}

LTD =largest tumour dimension

$\mathbf{R D}=$ retinal detachment
The sensitivity of this sign $(94 \%)$ is naturally offset by a low specificity (19\%). Its usefulness clinically is also limited by its strong correlation with LTD $(p<0.0001)$. This is not surprising since expansion of the choroidal tumour, with inward bulging towards the vitreous, causes the retina to become stretched out over the summit of the mass. ${ }^{22}$ It would not, therefore, be expected to provide any additional information to LTD.

A summary of multifactorial analyses of other studies is given in Table 5. No two studies concur, but cell type and tumour size are significant variables in every group. Until recently, however, histology has been unavailable before enucleation. With the advent of safe tumour biopsy, both by excision ${ }^{23}$ and fine needle aspiration, ${ }^{24}$ this is likely to change, and knowledge of cell type could play a major role in clinical management. In this study, presence or absence of epithelioid cells had a reasonable sensitivity and specificity. Cell type did not correlate with LTD $(p<0 \cdot 12)$ and, with glaucoma, would be expected to contribute independently to the prediction of metastases. This is confirmed in the multivariate combination in Table 3 , and is also supported by Gamel $e$ t al who demonstrated an even weaker correlation between LTD and cell type $(\mathrm{p}<0 \cdot 26){ }^{25}$

The prognostic significance of cell type has implications for the not always perfectly reproducible Callender system. The Callender classification scheme places the tumour into one of four $^{18}$ to $\operatorname{six}^{17}$ subgroups, although the cells present in uveal melanomas actually represent a continuous spectrum of morphological change. The fact that this classification has repeatedly emerged as significant augurs well for the clinical value of an even better system, one that examines the characteristics of the cell as part of a continuum rather than limited subgroups. Such reproducible, quantifiable, and objective characteristics have been investigated over the past decade. The standard deviation of nucleolar area (SDNA) and mean area of the 10 largest nucleoli (MLN) have been equally and significantly correlated with malignancy of uveal melanomas. ${ }^{25}$

Table 5 A summary of multivariate analysis in different studies

\begin{tabular}{|c|c|c|c|}
\hline Study group & Methodology & Combinations & $\begin{array}{l}\text { Independent variables } \\
\text { (in order of significance) }\end{array}$ \\
\hline Kidd et al (1986) & $\begin{array}{l}\text { Cox proportional hazards } \\
\text { Log-logistic model }\end{array}$ & $\begin{array}{l}\text { Cell type and tumour extension } \\
\text { correlated with tumour size }\end{array}$ & 1 Tumour volume \\
\hline Seddon et al (1983) & $\begin{array}{l}\text { Cox proportional hazards } \\
\text { model }\end{array}$ & & $\begin{array}{l}1 \text { No of epithelial } \\
\text { cells/HPF } \\
2 \text { LTD } \\
3 \text { Anterior to equator } \\
4 \text { Invasion to line of } \\
\text { transection } \\
5 \text { Increased } \\
\text { pigmentation }\end{array}$ \\
\hline Packard (1980) & Stepwise discriminant analysis & $\begin{array}{l}1 \text { Age and cell type } \\
2 \text { In spindle tumours, pigmentation } \\
3 \text { In mixed and epithelioid cell } \\
\text { tumours, size }\end{array}$ & \\
\hline & Stepwise discriminant analysis & LTD, cell type and optic nerve spread & $\begin{array}{l}1 \text { LTD } \\
2 \text { Cell type }\end{array}$ \\
\hline $\begin{array}{l}\text { (tumours with } \\
\text { extrascleral spread) }\end{array}$ & Bayesian multifactorial analysis & & 3 Optic nerve invasion \\
\hline $\begin{array}{l}\text { McLean et al }(1977) \\
\text { (tumours < } 1400 \mathrm{~mm} \text { ) }\end{array}$ & Discriminant function analysis & $\begin{array}{ll}1 & \text { Cell type } \\
2 & \text { LTD } \\
3 & \text { Scleral extension } \\
4 & \text { Mitotic activity }\end{array}$ & \\
\hline Coleman et al (1993) & $\begin{array}{l}\text { Cox proportional hazards } \\
\text { model }\end{array}$ & LTD, glaucoma, and cell type & $\begin{array}{l}1 \text { Glaucoma } \\
2 \text { Cell type } \\
3 \text { LTD }\end{array}$ \\
\hline
\end{tabular}


DNA quantitation by flow cytometry has been shown in one study to be a better parameter than the inverse SDNA. ${ }^{26} \mathrm{~A}$ study from our laboratory using DNA image analysis, and requiring a sample size of only 100 cells, has suggested that spindle A cells are, like most benign cells, noncycling, and that tetraploid and aneuploid peaks are mainly occupied by the more pleomorphic spindle B and epithelioid cell types. ${ }^{27}$

It is apparent that although important trends have emerged from retrospective prognosis studies, such as relevance of size and cell type, it is not possible to reach firm conclusions because of lack of uniformity of study designs. This is confirmed by Markowitz et al who noted the absence of information on study design and methods in $50 \%$ of 76 melanoma studies from 1966 to $1988 .{ }^{28}$ Survival rates following enucleation are broadly similar in all study groups reported. The Collaborative Ocular Melanoma Study (COMS) in America is the first major prospective study designed to examine the natural history of patients with uveal melanomas following management by either enucleation or radiotherapy. We suggest a transcontinental approach and the creation of a strict European multicentre protocol for pooling of prospective clinical and pathological information. This is essential with the imminent availability of histological information before management, particularly now that many different forms of therapy are available, in order to ensure the best possible survival rates and lowest morbidity for our patients.

The authors wish to acknowledge the kind assistance of Ronan Conroy, Department of Epidemiology, Royal College of Surgeons in.Ireland, with the preparation of the database.

1 Newton FH. Malignant melanoma of the choroid. Report of a case with clinical history of 36 years and follow-up of 32 years. Arch Ophthalmol 1965; 73: 198-9.

2 Zimmerman LE, McLean IW, Foster WD. Does enucleation of the eye containing a malignant melanoma prevent or accelerate the dissemination of tumour cells? $\mathrm{Br} \mathcal{F} O$ phthalmol 1978; 62: 420-5.

3 Seigel D, Myers M, Ferris F, Steinhorn SC. Survival rates after enucleation of eyes with malignant melanoma. Am F Ophthalmol $1979 ; 87: 761-5$.

4 Manschot WA, van Peperzeel HA. Choroidal melanoma enucleation or observation? Arch Ophthalmol 1980; 98: 71-7.

5 Kidd MN, Lyness RW, Patterson CC, Johnston PB, Archer DB. Promostic R , Patterson CC, Johnston PB, Archer choroid: a retrospective survey of cases occurring in
Northern Ireland between 1965 and 1980. Trans Ophthalmol Soc UK 1986; 105: 114-21.

6 Raivio I. Uveal melanoma in Finland: an epidemiological, clinical, histological and prognostic study. Acta Ophthalmo 1977, suppl 133: 4-64.

7 Jensen OA. Malignant melanomas of the human uvea - recent follow-up of cases in Denmark, 1943-1952. Acta Ophthalmo (Kbh) 1970; 48: 1113-28.

8 Jensen OA. Malignant melanomas of the human uvea - 25 year ollow-up of cases in Denmark, 1943-1952. Acta Ophthalmo 1982; 60: 161-82.

9 Packard RBS. Pattern of mortality in choroidal malignant melanoma. Br $\mathcal{F}$ Ophthalmol 1980; 64: 565-75.

10. Benjamin B, Cumings JN, Goldsmith AJB, Sorsby A. Prognosis in uveal melanoma. Brf Ophthalmol 1948; 32: 729-47.

11 Paul EV, Parnell BL, Fraker M. Prognosis of malignant melanomas of the choroid and ciliary body. Int Ophthalmol Clin 1962; 2: 387-402.

12 Seddon JM, Albert DM, Lavin PT, Robinson N. A prognostic factor study of disease-free interval and survival following enucleation for uveal melanoma. Arch Ophthalmol 1983; 101: enucleation $1894-5$.

13 Diener-West M, Hawkins BS, Markowitz JA, Schachat AP. A review of mortality from choroidal melanoma. II. A metareview of mortality from choroidal melanoma. II. A metaanalysis of 5-year mortality rates following enucleation,

14 Thomas JV, Green R, Maumenee AE. Small choroida melanomas - a long-term follow-up study. Arch Ophthalmo 1979; 97: 861-4.

15 Schachat AP. Collaborative ocular melanoma study. In: Ryan SJ, ed. Retina St Louis: Mosby, 1989; 1: Chapter 49: 733-6.

16 Folberg G, Gamel JW, Greenberg RA, Donosa LA, Naids RM. Comparison of direct and microslide pathology measurements of uveal melanomas. Invest Ophthalmol Vis Sci 1985; 26: 1788-91.

17 Callender GR, Wilder HC, Ash JE. Five hundred melanoma of the choroid and cilary body followed five years or longer. Am $\mathcal{O}$ Ophthalmol 1942; 25: 962-7.

18 McLean IW, Foster WD, Zimmerman LE, Gamel JW. Modifications of Callender's classification of uveal melanoma at the Armed Forces Institute of Pathology. Am 7 Ophthalmol 1983; 96: 502-9.

19 Zimmerman LE, McLean IW. Do growth and onset of symptoms of uveal melanomas indicate subclinical metastasis. Ophthalmology 1984; 91: 685-91.

20 Flocks M, Gerende JH, Zimmerman LE. The size and shape of malignant melanomas of the choroid and cilary body in of malignant melanomas of the choroid and cilary body in tical study of 210 tumours. Trans Am Acad Ophthalmol tical study of 210 tumours.

21 Shields CL, Shields JA. Glaucoma secondary to intraocula tumours. In: Roy FH, Fraunfelder FT, eds. Current ocular tumours. In: Roy FH, Fraunfelder FT, eds.

22 Zimmerman LE. Malignant melanoma of the uveal tract. In: Spencer WH, ed. Ophthalmic pathology. Vol 3. Philadelphia: Saunders, 1986: 2125

23 Foulds WS. The uses and limitations of intraocular biopsy. Eye 1992; 6: 11-27.

24 Char DH, Miller TR, Ljung BM, Howes EL, Stoloff A. Fine needle aspiration in uveal melanoma. Acta Cytol 1989; 33: 599-605.

25 Gamel JW, McCurdy JB, McLean IW. A comparison of prognostic covariates for uveal melanoma. Invest Ophthalmol Vis Sci 1992; 33: 1919-22.

26 Meecham WJ, Char DH. DNA content abnormalities and prognosis in uveal melanoma. Arch Ophthalmol 1986; 104 $1626-9$.

27 Coleman K, Baak JPA, Mullaney J, Curran B, Tiernan D, Farrell $M$, et al. Deoxyribonucleic acid ploidy studies in choroidal melanomas. Am f Ophthalmol 1993; 115: 376-83.

28 Markowitz JA, Hawkins BS, Diener-West M, Schachat AP. A review of mortality from choroidal melanoma. I. Quality of published reports, 1966 through 1988. Arch Ophthalmol published reports,
1992; 110: $239-44$. 